\title{
The possibilities of music therapy in the context of integrated psychotherapy / Knobloch
}

\section{Las posibilidades de la musicoterapia en el contexto de la psicoterapia integrada / Knobloch}

Peter Kusý ${ }^{1}$

Recibido: 13/11/2019

Aceptado: 19/05/2020

\begin{abstract}
Purpose of this paper is to describe the possibilities of music therapy in the context of Integrated Psychotherapy / Knobloch. The main pillar of music therapy in the psychotherapeutical process is created by Interpersonal Hypothesis of Music, which is based on an idea that the music reflects interpersonal tendencies which independent observer can determine with the certainty beyond a mere chance. Music is able to induce a state that similarly like dreams activates interpersonal processes in person's Group Scheme, and in fantasy even satisfies some interpersonal needs and activates interpersonal tendencies. This relates to all people alike. One of the most important tools of music therapy is Circumplex that represents eight categories of interpersonal tendencies (dominance and submission, affiliation and autonomy, exhibition of high and poor quality, fight and escape). There are also used various techniques of passive (receptive) and active components of music therapy always in accordance with the principle of Interpersonal Hypothesis of Music which together with the Circumplex and Group Scheme can function as effective secondary tool in therapeutic practice.
\end{abstract}

Key words: music therapy, interpersonal hypothesis of music, circumplex, group scheme, interpersonal tendencies, integrated psychotherapy

Cómo citar. Kusý, P. (2019). Las posibilidades de la musicoterapia en el contexto de la psicoterapia integrada / knobloch. Revista de Investigación en Musicoterapia, 3, 148-155

\section{INTRODUCTION}

Humans have been in its journey through life always accompanied by music. They were in various roles (listeners, musicians, singers or composers) and with music they always gained various artistic experiences. Music has become a kind of human communication - with a man with himself, and also with his surroundings, the world. Knobloch $(1993 ; 1964)$ states that sounds have (with their own dynamic, rhythmic and melodic aspects) serious effects on animals and humans. Different frequencies affect the rhythm of breath of many animal species (from fishes to humans). The rhythm changes can be varied as a heartbeat, or rhythm of breath etc. In the history of mankind, before a language was developed, musical qualities of sounds probably played a central role in a communication of our ancestors. Nowadays, in

\footnotetext{
1 Department of Educational Studies, Faculty of Education, Trnava University in Trnava, e-mail: peterkusy7@gmail.com
} 
primitive cultures different songs still have important integration functions in a group (military songs, hunting songs, funerals, laments, work songs), or even to a certain extent coordinate dyadic interpersonal processes in a group (love songs, lullabies). In psychotherapy, the improvement of interpersonal relations is very often accompanied by a change in the sound quality of the patient's speech. Knobloch (1999) states that the music has a strong influence on current mood and social behaviour. He convinced himself about this in psychotherapeutic practice (in the initial period of Integrated Psychotherapy) working with different types of patients. Since 1946, he has been organising singing sessions with patients singing national songs with piano accompaniment in one of the departments of psychiatric clinic in Prague. Later, in therapeutic community in Lobeč, he found that if group psychotherapeutic sessions had been preceded by music, singing and dancing, the work of a group was definitely more efficient. Use of music is thus an indispensable part, very important and effective component of group psychotherapy process within the system of Integrated Psychotherapy / Knobloch.

Following the interpersonal theories of personality, Knobloch created the interpersonal hypothesis of music, which forms the basis for interpersonal theory of music. The interpersonal hypothesis of music was originally designed, elaborated and verified by Knobloch et al. $(1964,1968)$ in the 60 s of the 20th century and gradually followed by other authors (e. g Linka, 1997; Doubravová, 1975, 1984, 1998, 2002, 2014; Kozel, 2015; Kusý, 2013, 2015, 2018 etc). Knobloch modified Leary's interpersonal diagram and adapted for the needs of musical perception. The interpersonal music circumplex represents a technical aid that had its rightful place in the experimental verification of the interpersonal hypothesis of music (see fig. 1 below). The advantage of the interpersonal circumplex is its versatility. So it can serve not only as a theoretical model, but also a research tool (see eg. Kusý, 2018) or music therapy tool.

\section{INTERPERSONAL HYPOTHESIS OF MUSIC AS A BACKGROUND}

Knobloch had formulated the hypothesis and later verified it on mature population in several phases. It is paradox that the theme which is in centre of interest of many musictherapists, musicologists, psychologists, sociologists and music teachers still has not been researched, explored and examined, and does not have exact concepts and terminological definitions.

Knobloch (1999) states that music has strong influence on current mood and social behaviour. In music there are also expressed interpersonal tendencies, which independent observer can determine with the certainty that is beyond chance. Music is able to induce a state, which - like a dream - activates interpersonal processes in patient's Group Scheme. In the imagination even satisfies some interpersonal needs. Music not only evokes feelings, but also enters to the Group Scheme, activates interpersonal tendencies and so does for all people alike. Experiencing the music moves us to interpersonal process and with the offered tendency we can either identify or respond complementary (aggression does not cause aggression, but fear). 
It's a fact that we all like some and dislike some music. Some is sympathetic, another is strange for us. Moreover, we often agree with others that we prefer the same specific kind of music and therefore form a listeners' community with other people. Interpersonal Hypothesis of Music examines what's the element which causes that the music attracts us, or on the other hand repels us (= interpersonal charge). Interpersonal Hypothesis further assumes that one of other important aspects of musical experience is participation on phantasy interpersonal processes, fictive movement in interpersonal space of a group. Result of such experience the listener generalizes in a Group Scheme, at first unwittingly and then wittingly, as an identified corrector of the experience with the group. The Group Scheme guides a man not only through the witting and recognized behaviour, but also in day phantasies and dreams. This way the Group Scheme can enter also into an art, with which we can manipulate in the phantasy. Maybe that is the reason why it is possible to manipulate also the Group Scheme of the listeners, whose via the music may be looking for confirmation of their own scheme and discover different Group Schemes via different types of music (e.g. for training reasons) (Doubravová, 2002).

Interpersonal Music Circumplex

Interpersonal behaviour is described using basic interpersonal tendencies, which are organized into circle diagram - the Circumplex. Knobloch criticized the original interpersonal diagram designed by Leary (1957) and created a supplemented and modified variant, where are added interpersonal tendencies, which are especially relevant when describing music. Knobloch extended the Interpersonal Circumplex for example with tendencies such as fear or flight and based it on ethological studies, where e.g. in case of animals there are flight, escape and fight tendencies (resp. in case of people fear, anger, etc.) as typical behavioural mechanisms (Knobloch \& Knobloch, 1999). Interpersonal Music Circumplex (Fig. 1) contains eight basic interpersonal tendencies (behaviour patterns), which are organized in circle diagram according to Knobloch (1995) as follows:

D+ Dominance - leads, directs, and advises, controls, dictates.

D- Submission - looks for a leader and accepts him, seeks help and advice, is submissive.

E+ Exhibition plus - exhibits the quality, draws attention, shows off, boasts with abundance of quality - power and beauty, attractiveness, wealth and intelligence.

E- Exhibition minus - exhibits with non-quality, stresses and points out lack of some quality - I am suffering, I am weak, sad, unhappy, and ill, I need compassion and care.

A+ Affiliation - open for contact and interaction, exhibits favour and intimacy, invites for cooperation, love and friendship.

A- Avoidance - keeps distance, moves away and isolates, separates, detaches, avoids contact.

F+ Fight - fight, aggression, anger - attacks, is annoyed, rages, curses and destroys.

F- Flight/Fear - flights, escapes, is in panic, and has fear-blocked flight and fright. 


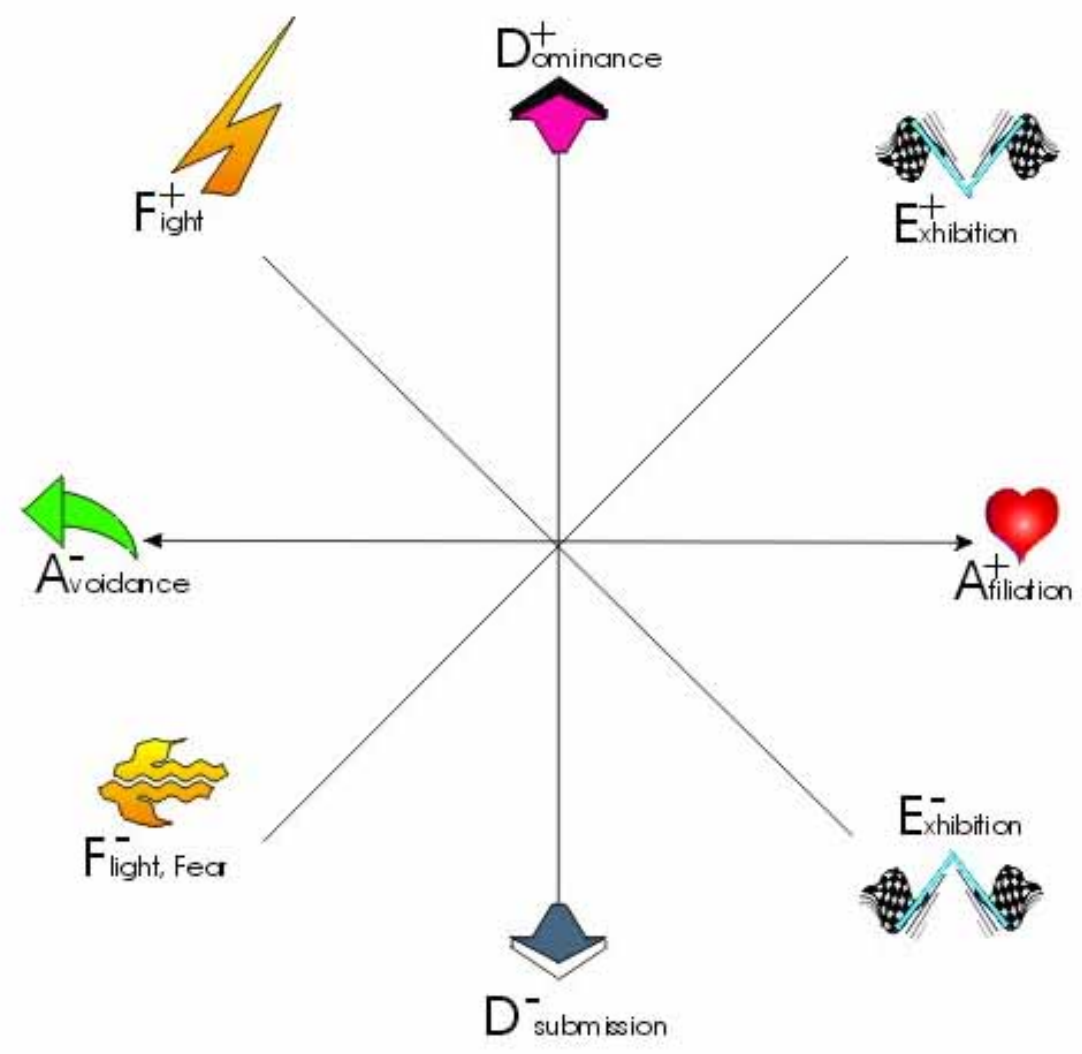

Fig. 1: Interpersonal Music Circumplex (Knobloch, 1995).

\section{THE POSSIBILITIES OF APPLICATION OF INTERPERSONAL THEORY OF MUSIC}

Music offers us many possibilities of application in helping professions. Disciplines like music pedagogics or music therapy have been rapidly growing in last few decades. Great advantage of Knobloch's Interpersonal Hypothesis of Music is a fact that it is not only a theoretical construct, but also has application potential as part of psychotherapeutic process in form of music therapy (e.g. Knobloch \& Knobloch, 1993, 1999; Kusý, 2013), or via music mediation in a small social group. According to Knobloch (1993) it can be very useful tool for empathy development - the practice shows that it not only develops empathy to music, but also creates basics for empathy development towards other people. Doubravová (2002) adds that the Interpersonal Hypothesis of Music enables to take into account such features of music, which have been omitted by traditional musicology, music psychology or anthropology till these days. We are talking particularly about participation on music, acquisition and identification of what is close to us, and also of what is on the other hand distant from us and seems strange to us (cultivation, acceptance and comprehension of the 
different). Therefore, according to Doubravová, the music may function as a medium in emotional intelligence and empathy development.

Expressive and Receptive Music Therapy as Interpersonal Process

We can differentiate and categorize possibilities of music utilization in several ways. It is possible to gather inspiration in analogical music-therapeutic concepts, where according to Linka (1997) there is used the most basic dichotomy perception based on participation on a motivated musical action on receptive and active form. ${ }^{2}$

Linka (1997) states that the live, produced music (expressive form of music therapy) has and advantage of social experience and use of visual element of interpretation, which some individuals listening to the music welcome as same as eventual additional possibility to enter into conversation with the interpret, particularly when they find an acquaintance among them (including members of the group). It is very interesting to mention a method of Moreno (2005) as an active element of music therapy, which is called psychodrama. Moreno poses the opinion that the base of the use of music psychodrama is psycho-dramatic music improvisational chorus. Its task is to create an improvised music, which supports varied spectrum of emotions in every point of time. Despite the spectrum of human emotions is relatively wide, it is possible to sort their musical expression into several extensive representative categories. The emotional categories may include e.g. sadness, anxiety, panic, joy, fear, peace, desire, nostalgia, melancholia and more. Moreno's emotional categories are partially comparable with categories which appear simultaneously during interpersonal tendencies of above mentioned Interpersonal Music Circumplex (see Fig. 1).

The receptive form is generally oriented at intentional or spontaneous reception of sounds and music. Such musical procedures have substantiation in practice and show positive results not only in clinical area (music therapy), but also in pedagogics (Kántor, Lipský \& Weber., 2009). Zeleiová (2007) states that the attention is in this case oriented particularly on listening to the music, sound, noise, or silence. Mátejová (1992) considers the receptive form to be such action, during which pointed, systematic and intensive effect of music on the listener's psychics occurs, which happens together with preservation of a state of physiological serenity. In such world of music perception the patient turns into an active participant of visual action of music, which enriches him/her at the level of his/hers individual experience world. Linka (1997) considers the receptive form to be passive listening, during which we can perceive the music, or to be engaged into another action (e.g. painting, reading, working, work out, dancing, etc.), a »non-musical« activity. The music which we use during the receptive from can be live (interpreted by us), or reproduced. The live music has, according to Linka (1997), great advantage of social experience (especially if we listen to the music in a group of people) and use of visual element of interpretation, which may create an important part of communication for some recipients. On the other hand, there

${ }^{2}$ In context of our problematics we talk about active music therapy as an expressive form of music therapy.

Revista de Investigación en Musicoterapia, 3, 2019, pp.148-155 
are some listeners, which prefer the reproduced music. Linka (1997) further states that reproduction allows easier connection of the recording itself with complementary acoustic inputs (e.g. spoken word - heterosuggestion, mood-creating, in other way motivated nonmusical sounds and so on).

Schwabe (1987, according to Mátejová \& Mašura, 1992) says that both forms (receptive and active) have its individual and group form of realisation. This is valid also for possibilities of usage of music in process of Integrated Psychotherapy. However, it is always necessary to consider the Interpersonal Hypothesis of Music and strive to musically affect in conformity with its principles. Music that we use in the process of Integrated Psychotherapy is becoming an experience for the patient, which activates interpersonal processes in scope of Group Schema of every individual. Fig. 2 illustrates possible movement in scope of Group Schema which can be activated due to the impact of music. Such musical impact should be intentional, purposive and systematic. A music therapist should know the music biography of the patient as a framework of anamnesis (musical history, education, preferences, etc.), and should also know what features and interpersonal charge the specific music contains. The music therapy and individual musical techniques are applied rather partially in Integrated Psychotherapy, as a supplementary or marginal method. Anyway, they form important part of therapeutic process and the music can often function as an impulse for "therapeutic breakthrough" in a long-term process.

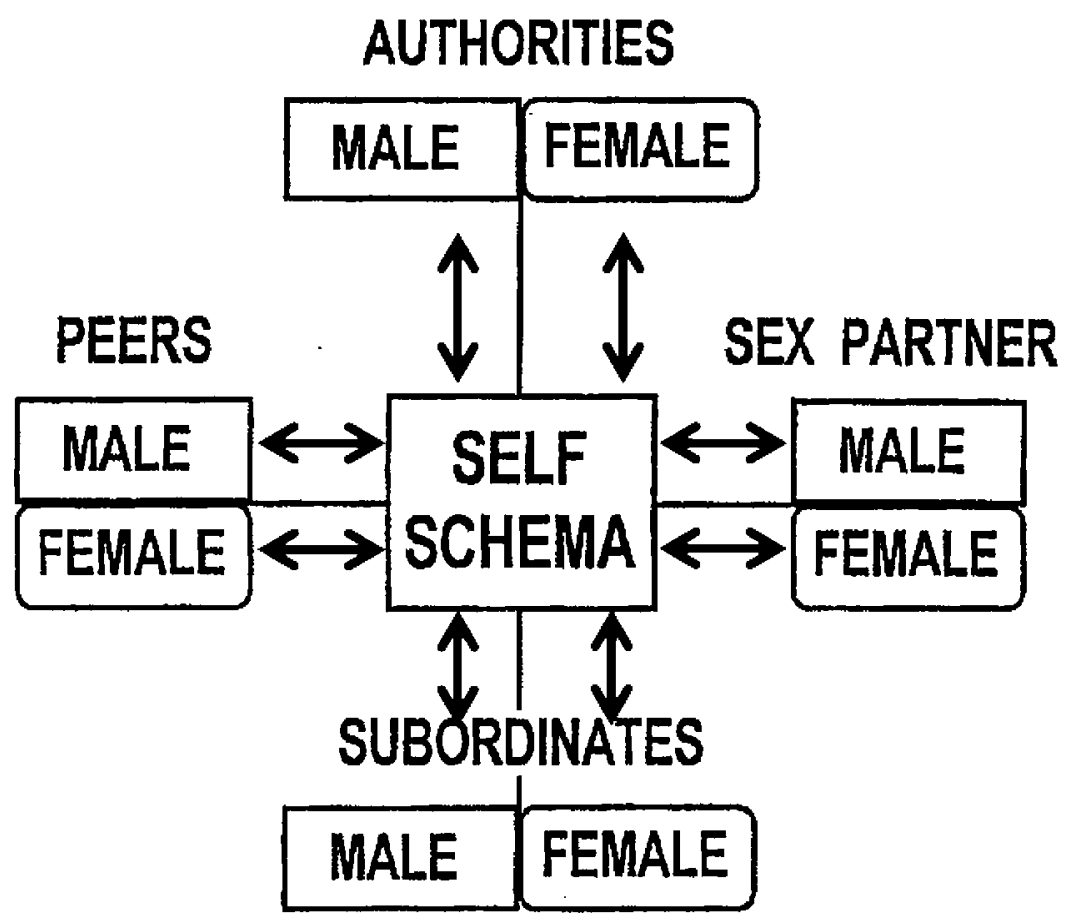

Fig. 2.: Music in Group Schema. 


\section{CONCLUSION}

Our goal was to provide a brief overview of the use of music therapy in the Integrated Psychotherapy context and to broaden the horizons of all the people who are interested in use of music, its effect on human and applications in therapeutic practice. Primarily, we focused on Interpersonal Hypothesis of Music, which is the main concept of music therapy in Integrated Psychotherapy / Knobloch. Principles of interpersonal hypothesis of music have not only theoretical, but also applicative character. We believe we have at least partially reached the goal and informed readers about further possibilities of music usage in a therapeutic process in continuum with the methods of Integrated Psychotherapy / Knobloch.

The use of music and techniques of music therapy has its place in the Integrated Psychotherapy and is relevant for therapeutic process. By using music, therapists can learn about their patients (diagnose), uncover their preferences, the nature of emotion, level of intelligence, speed of reactions, communication habits, interpersonal conflicts, or self-defeating behaviour. Music can also be used to invoke abreaction, stimulates imagination and fantasy, associations, restructures personality, harmonizes and activates the person physically, intellectually and emotionally. Music can calm the person down, induce pleasurable experiences and satisfy aesthetic needs, develop interests, enrich phenomenological experience, or make the persons to think about them and about life. The importance of using music in Integrated Psychotherapy is therefore irreplaceable.

\section{REFERENCES}

Doubravová, J. (1975). Interpersonální význam hudby a hudební sémiotika. Hudební věda, 12(2), pp. 154-164.

Doubravová, J. (1984). Musical Semiotics in Czechoslovakia and Interpersonal Hypothesis of Music. International Review for the Aesthetics and Sociology of Music. 1. pp. 31-38.

Doubravová, J. (1998). Dialog a imaginace. Interpersonální diagnoza umění(m). Praha: Editio Supraphon.

Doubravová, J. (2002). Sémiotika v teorii a praxi. 1. ed. Praha: Portál.

Doubravová, J. (2014). The Hidden Unity. An Experimental View of Aesthetics and Semiotics of Music in the Czech Milieu. Peter Lang.

Knobloch, F. (1995). The Interpersonal Meaning of Music and Ethology. ASCAP. 6 (7). Available at: http://cogweb.ucla.edu/Abstracts/Knobloch_95.html

Knobloch, F., Juna, J., Junová, H. \& Koutský, Z. (1968). On interpersonal hypothesis in the semiotic of music, Kybernetika, 4 (4), pp. 368-382. Available at: http://dml.cz/bitstream/handle/10338.dmlcz/124399/Kybernetika_04-1968-4_7.pdf

Knobloch, F. \& Knobloch, J. (1993). Integrovaná psychoterapie. Praha: Grada Publishing. 
Knobloch, F. \& Knobloch, J. (1999). Integrovaná psychoterapie vakci. Praha: Grada Publishing.

Knobloch, F., Postolka, M. \& Srnec, J. (1964). Musical experience as interpersonal process, In Psychiatry Journal for the study of interpersonal processes, Vol. 27, No. 4, pp. $259-265$.

Kozel, D. (2015). Interpersonální hypotéza hudby a hlubinně hermeneutické hledání smyslu uměleckého díla. Musicologica Brunensia. 50 (1), pp. 205-212.

Kusý, P. (2013). Využitie muzikoterapie v rámci Integrovanej psychoterapie. Arteterapie. No. 31. pp. 77-84.

Kusý, P. (2015). Interpersonálna teória hudby a hudobná mediácia u detí. In Krajčí, P. \& Priesterová, K. 2015. Dimenzia muzikoterapie v praxi, výskume a edukácii. Bratislava: IRIS, pp. 166-172.

Kusý, P. (2018). Interpersonálna teória hudby - teoretické východiská, výskumné rezultáty a možnosti aplikácie. Trnava: Typi Tyrnaviensis.

Leary, T. (1957). Interpersonal diagnosis of personality. New York: Ronald Press.

Linka, A. (1997). Kapitoly z muzikoterapie. 1. ed. Rosice u Brna: Gloria, 158 p.

Mátejová, Z. \& Mašura, S. (1992). Muzikoterapia v špeciálnej a liečebnej pedagogike. 1. ed. Bratislava: SPN, 202 p.

Moreno, J. J. (2005). Rozehrát svou vnitřni hudbu: Muzikoterapie a psychodrama. 1. ed. Praha: Portál. 128 p.

Zeleiová, J. (2002). Muzikoterapia - dialóg s chvením. Bratislava: Ústav hudobnej vedy SAV, $310 \mathrm{p}$.

Zeleiová, J. (2007). Muzikoterapie: východiská, koncepty, principy a praktická aplikace. 1. ed. Praha: Portál, 256 p. 